FINANCIAL: Jurnal Akuntansi

Published by Program Studi Akuntansi STIE Sultan Agung Volume 6-Nomor 2, Desember 2020, (HIm 179-187)

ISSN-P: 2502-4574, ISSN-E: 2686-2581

Available online at: https://financial.ac.id/index.php/financial

\title{
ANALISIS INVESTASI PEMERINTAH PUSAT PADA LEMBAGA KEUANGAN INTERNASIONAL
}

\author{
Hari Sugiyanto \\ Jurusan Akuntansi, Politeknik Keuangan Negara STAN, Jl. Bintaro Utama Sektor V, Bintaro Jaya, \\ Tangerang Selatan, Banten, 15222, Indonesia \\ E-mail: hari.sugiyanto@pknstan.ac.id
}

\begin{abstract}
Abstrak
Investasi pemerintah adalah penempatan sejumlah dana dan/atau barang untuk memperoleh manfaat ekonomi seperti bunga, dividen, dan royalti, atau manfaat sosial sehingga dapat meningkatkan kemampuan pemerintah dalam rangka pelayanan kepada masyarakat. Dalam laporan keuangan pemerintah pusat, pembayaran kewajiban kepada Lembaga Keuangan Internasional dimasukkan sebagai penanaman modal permanen (investasi permanen) pemerintah. Tujuan penelitian adalah untuk menganalisis investasi pemerintah pada lembaga keuangan internasional dan manfaat investasi tersebut. Penelitian dilakukan dengan analisis wacana terhadap fenomena investasi pemerintah pada lembaga keuangan internasional. Berdasarkan pengamatan terhadap data pendapatan Negara bukan pajak pada pemerintah pusat, dalam kurun waktu tahun 2004 sampai dengan tahun 2019 penanaman modal pemerintah tersebut tidak menghasilkan pendapatan dalam bentuk dividen, bunga, atau bentuk pendapatan lainnya. Berdasarkan nota keuangan pemerintah tahun 2020, pemerintah memperoleh manfaat sosial dari penanaman modal tersebut. Pemerintah disarankan untuk meninjau kembali pencatatan pembayaran iuran kepada Lembaga Keuangan Internasional tersebut dari investasi permanen ke beban, mengingat tidak ada pendapatan dividen, bunga atau lainnya yang diperoleh pemerintah.
\end{abstract}

Kata kunci: manfaat ekonomi, investasi, manfaat sosial

\section{ANALYSIS OF CENTRAL GOVERNMENT INVESTMENTS IN INTERNATIONAL FINANCIAL INSTITUTIONS}

\begin{abstract}
Government investment is the placement of several funds and/or goods to obtain economic benefits such as interest, dividends, and royalties, or social benefits to increase the government's ability to provide services to the public. In the financial statements of the central government, the payment of obligations to international financial institutions is included as a permanent investment (permanent investment) of the government. The research objective is to analyze government investments in international financial institutions and the benefits of these investments. The research was conducted with a discourse analysis of the phenomenon of government investment in international financial institutions. Based on observations of data on non-tax state income at the central government, during the period 2004 to 2019, the govern-ment investment did not generate income in the form of dividends, interest, or other forms of income. Based on the 2020 government financial notes, the government has obtained social benefits from the investment. The government is advised to review the recording of contribution payments to the International Financial Institution from permanent investment to expense, given that there is no dividend, interest, or other income earned by the government.
\end{abstract}

Keywords: Economic benefits, investment, social benefits

Article History: Received: 22 Okt 2020 Revised: 17 Nop 2020 Accepted: 23 Nop 2020 


\section{PENDAHULUAN}

Dalam bidang perekonomian, investasi merupakan langkah awal dalam suatu produksi dan merupakan salah satu faktor penting dalam peningkatan pertumbuhan ekonomi. Sektor komersial/ swasta mendefinisikan nvestasi sebagai penanaman aset, baik dalam bentuk uang atau aset lainnya yang dilakukan oleh sebuah perusahaan atau perorangan untuk jangka waktu tertentu dan bertujuan untuk memperoleh imbal balik yang lebih besar pada masa depan. Sedangkan pemerintah dalam PP Nomor 71 Tahun 2010 tentang
Standar Akuntansi Pemerintahan (SAP) mendefinisikan investasi sebagai suatu aset yang dimaksudkan untuk memperoleh manfaat ekonomi seperti bunga, dividen, dan royalti, atau manfaat sosial sehingga dapat meningkatkan kemampuan pemerintah dalam rangka pelayanan kepada masyarakat.

Berdasarkan data yang terdapat dalam Laporan Keuangan Pemerintah Pusat (LKPP) Tahun 2019 (audited), jumlah total investasi Pemerintah Pusat senilai Rp 3.001 Triliun Rupiah. (Gambar $1)$.

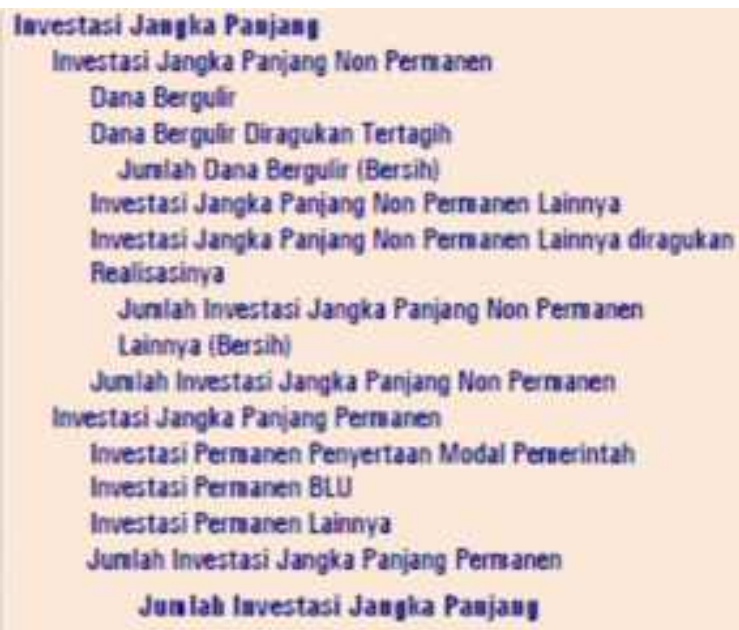

\section{Gambar 1. Investasi Pemerintah TA 2019}

Berdasarkan data LKPP Tahun 2019 tersebut, investasi terbanyak adalah investasi Permanen Penyertaan Modal Pemerintah senilai Rp2.397 Triliun. Investasi permanen penyertaan modal pemerintah adalah investasi jangka panjang yang dimaksudkan untuk dimiliki secara berkelanjutan, dalam bentuk penyertaan modal kepada perusahaan negara atau lembaga keuangan internasional.

Sebagai bagian dari masyarakat dunia, negara Indonesia telah berpartisipasi aktif dalam berbagai organisasi internasional, baik organisasi umum seperti PBB, ASEAN, OKI dan lain-lain, maupun lembaga keuangan internasional. Lembaga Keuangan Internasional (selanjutnya disingkat LKI) adalah lembaga keuangan multilateral atau regional yang terdapat investasi Pemerintah Republik Indonesia di dalamnya (Peraturan Menteri Keuangan Nomor PMK Nomor 50/PMK.010/2019). Sampai dengan tahun 2019, investasi pemerintah RI pada LKI adalah Rp 22,637 Triliun. Investasi Pemerintah pada LKI tersebut tersebar di sejumlah organisasi antara lain Asian Development Bank (ADB), World Bank Group, Bank 
Pembangunan Islam (IDB), International Islamic Trade Finance Corporation (IITFC), International Fund Agricultural Development

(IFAD),

ASEAN

Infrastructure Fund, dan Asian Infrastructure Investment Bank (LKPP 2019).

PMK Nomor 169/PMK.05/2018 tentang Sistem Akuntansi dan Pelaporan Keuangan Investasi Pemerintah menjelaskan bahwa salah satu tujuan investasi pada LKI adalah memperoleh pendapatan berupa kas, baik berupa dividen, bunga, atau pendapatan lainnya. Namun berdasarkan pengamatan terhadap pendapatan pemerintah tahun 2004 sampai dengan 2019, pemerintah belum memperoleh hasil atas investasi yang ditanamkan pada LKI tersebut.

Berdasarkan uraian pada latar belakang, maka rumusan permasalahan pada penelitian ini adalah apakah pemerintah RI telah mendapatkan manfaat atas investasi pada LKI dan apakah sudah tepat dalam mencatat pembayaran rutin kepada LKI sebagai investasi jangka panjang?

\section{LANDASAN TEORI}

Investasi adalah penundaan konsumsi di waktu sekarang dan dipindahkan ke dalam aset produktif selama priode waktu tertentu (Hartono M, 2015). Investasi adalah penanaman modal yang pada masa mendatang diharapkan akan menghasilkan tambahan dana (Meltzer, 2009). Dengan kata lain, investasi adalah bentuk pengorbanan harta di masa sekarang dengan mengharapkan perolehan keuntungan di masa depan. Menurut Psacharopoulos \& Patrinos, (2004) investasi dibedakan menjadi dua yaitu a) Investasi dalam bentuk aset berwujud, yaitu investasi dalam bentuk aset berwujud fisik seperti emas, logam mulia dan sebagainya; b) Investasi dalam bentuk surat berharga/sekuritas, yaitu investasi berupa saham atau obligasi yang dibeli dari pasar surat berharga dan secara umum diawasi oleh lembaga tertentu.

Investasi tidaklah bebas risiko, karena adanya ketidakpastian dalam return yang diperoleh (Dixit \& Pindyck, 2012). Investasi pada sektor publik (termasuk pemerintahan) sedikit berbeda dengan investasi pada sektor komersial. Investasi publik memiliki kaitan yang erat dengan penganggaran belanja permodalan/ investasi. Penganggaran modal/investasi merupakan proses untuk menganalisa dan membuat perencanaan kegiatan/proyek dan memutuskan apakah kegiatan/proyek tersebut bisa diakomodasi oleh anggaran permodalan/ investasi (Mankiw, 2013).

Pembangunan merupakan syarat mutlak bagi kelangsungan kehidupan suatu bangsa. Merencanakan pembangunan yang berkesinambungan merupakan langkah krusial yang harus dilakukan oleh suatu pemerintahan (negara) dengan tujuan untuk menciptakan kondisi bagi masyarakat untuk dapat menikmati lingkungan yang menunjang bagi hidup sehat, umur panjang dan menjalankan kehidupan yang produktif menuju keberhasilan pembangunan. Kapasitas dasar pembangunan ekonomi mencakup kecukupan (sustenance), jati diri (selfesteem), serta kebebasan (freedom) (Gupta, 1984). Kecukupan dalam hal ini merupakan kemampuan untuk memenuhi kebutuhan-kebutuhan dasar yang meliputi pangan, sandang, papan, kesehatan, dan keamanan. Termasuk dalam self-esteem (jati diri) adalah keikutsertaan Indonesia dalam keanggotaan di Lembaga Keuangan 
Internasional (Danawati, Bendesa, \& Utama, 2016).

Berdasarkan Peraturan Menteri Keuangan Nomor 169/PMK.05/2018 tentang Sistem Akuntansi dan Pelaporan Keuangan Investasi Pemerintah, definisi investasi pemerintah adalah penempatan sejumlah dana dan/atau barang untuk memperoleh manfaat ekonomi seperti bunga, dividen, dan royalti, atau manfaat sosial sehingga dapat meningkatkan kemampuan pemerintah dalam rangka pelayanan kepada masyarakat. PP Nomor 71 Tahun 2010 menjelaskan bahwa manfaat sosial adalah manfaat yang tidak dapat diukur dengan satuan uang namun berpengaruh terhadap peningkatan pelayanan pemerintah pada masyarakat luas maupun golongan masyarakat tertentu. Misalnya pemerintah menyalurkan dana bergulir kepada kelompok tani melalui BLU Investasi, maka tujuan utama investasi tersebut adalah agar taraf perekonomian petani meningkat, dan tujuan berikutnya adalah agar pemerintah memperoleh hasil berupa bunga pinjaman.

\section{METODE PENELITIAN}

Metode penelitian yang digunakan adalah pendekatan analisis wacana atau yang sering disebut text analysis (Hamad, 2004). Penulis menggunakan metode ini karena terdapat realitas kompleks yang akan dijabarkan. Metode interpretasi terhadap teks digunakan untuk memperoleh pemahaman lebih dikenal sebagai hermeneutika. Dalam pandangan ini, pengertian investasi pemerintah yang terdapat pada Akuntansi Pemerintahan tidak bisa dilepaskan dari suatu konteks tertentu, namun tergantung pihak yang menafsirkan, situasi, kepentingan, kebiasaan dan latar belakang lainnya. Dengan pendekatan ini, penulis tidak mengajukan suatu hipotesis penelitian, tetapi ingin mengintrepretasikan suatu wacana tentang penempatan dana pemerintah pada Lembaga Keuangan Internasional. Dalam literatur, wacana dapat dibagi menjadi tiga hal yaitu: (a) konseptual, yang berarti bahwa wacana adalah domain umum dari pernyataanpernyataan, yaitu semua ujaran yang bermakna dan terjadi di dunia nyata, (b) penggunaannya, yaitu sekumpulan pernyataan yang dapat dikelompokkan dalam konseptual tertentu, dan (3) penjelasannya, yaitu praktik yang terjadi untuk menjelaskan pernyataan (Sobur, 2006). Sumber data yang digunakan adalah peraturan, jurnal yang terpublikasi, buku, artikel dan lain-lain.

Analisis dalam pendekatan ini adalah suatu eksplorasi atas konsekuensi yang timbul dari topik yang dipilih. Data yang digunakan adalah data sekunder berupa peraturan, publikasi ilmiah dan dokumentasi lainnya yang tentu saja terkait dengan penelitian tentang investasi, khususnya investasi pemerintah.

\section{HASIL DAN PEMBAHASAN}

Pemerintah mendefinisikan investasi sebagai suatu aset yang dimaksudkan untuk memperoleh manfaat ekonomi seperti bunga, dividen, dan royalti, atau manfaat sosial sehingga dapat meningkatkan kemampuan pemerintah dalam rangka pelayanan kepada masyarakat. Dari definisi tersebut, secara garis besar pemerintah bertujuan memperoleh dua manfaat dalam investasi yang ditanamkan dalam suatu bidang, yaitu manfaat ekonomi dan manfaat sosial.

Terdapat sejumlah persamaan dan 
perbedaan antara akuntansi pemerintah dan akuntansi keuangan dalam metode penilaian investasi. Di dalam PP Nomor 71 Tahun 2010, pada PSAP 06 (Revisi tahun 2016) tentang Akuntansi Investasi dijelaskan bahwa akuntansi terhadap investasi permanen dibagi menjadi dua, yaitu metode biaya dan metode ekuitas. Metode biaya diterapkan apabila pemerintah memiliki investasi kurang dari $20 \%$. Dengan metode biaya, investasi dicatat sebesar harga perolehan, sedangkan penghasilan investasi diakui sebesar bagian hasil yang diterima dan tidak memengaruhi besarnya investasi. Sedangkan metode ekuitas diterapkan apabila kepemilikan pemerintah lebih dari $20 \%$ atau kurang dari 20\% namun memiliki pengaruh yang signifikan. Pada metode ekuitas, pemerintah mencatat investasi sebesar biaya perolehan dan ditambah bagian laba atau dikurangi dengan bagian kerugian setelah tanggal perolehan. Bagian laba yang diterima pemerintah akan mengurangi nilai investasi pemerintah.

Sehubungan dengan investasi pemerintah pada LKI, PMK Nomor 169/PMK.05/2018 menjelaskan bahwa investasi ini memiliki karakteristik sebagai investasi permanen yang sifatnya tidak bisa diperjualbelikan, dan penilaian investasinya menggunakan metode biaya. Apabila diperoleh pendapatan berupa kas, pemerintah mengakui sebagai Pendapatan Lain-lain pada saat kas diterima pada rekening kas umum negara berdasarkan dokumen yang sah.

Sedikit berbeda dengan akuntansi pemerintah, dalam akuntansi keuangan, apabila kepemilikan kurang dari $20 \%$, artinya investor tidak memiliki pengaruh sama sekali terhadap investee, dan akuntansi yang digunakan adalah metode biaya. Apabila kepemilikan antara $20 \%$ sampai dengan 50\%, maka investor dianggap memiliki pengaruh yang signifikan dalam perusahaan investee, dan akuntansi yang digunakan adalah metode ekuitas. Sedangkan apabila investasi yang ditanamkan lebih dari 50\%, berarti investor mengendalikan jalannya perusahaan investee, dan metode akuntansi yang digunakan adalah konsolidasi (Kolitz, 2014). Menurut PSAK 15 tentang Akuntansi untuk Investasi dalam Perusahaan Asosiasi, metode yang digunakan adalah metode Biaya dan metode Ekuitas.

\section{Investasi Pada LKI Bertujuan Memperoleh Manfaat Ekonomi}

LKPP tahun 2019 menyatakan bahwa penanaman modal Negara pada LKI dicatat sebagai investasi permanen sebesar kontribusi Pemerintah yang telah dibayar tunai maupun dalam bentuk penerbitan Promissory Notes. Di sisi lain, promissory notes disajikan sebagai kewajiban. Investasi pada LKI dinilai dengan menggunakan metode biaya. Manurut PP Nomor 71 Tahun 2010, dengan metode biaya, investasi dicatat sebesar biaya perolehan. Penghasilan atas investasi diakui sebesar bagian hasil yang diterima dan tidak memengaruhi besarnya investasi pada badan terkait. Metode biaya diterapkan apabila nilai investasi pemerintah pada LKI kurang dari $20 \%$.

Berdasarkan data yang berhasil dihimpun oleh penulis, investasi pemerintah RI pada LKI dilakukan secara bertahap dan dialokasikan setiap tahun dalam APBN. Pada tahun anggaran 2019, penambahan modal pada LKI adalah sebesar Rp 2.275.076.593.824,00 yang 


$\begin{array}{lllr}\text { digunakan untuk } & \text { ICD } & \text { sebesar } \\ \text { Rp42.120.677.000,00 } & & \text { IDB } \\ \text { Rp80.844.636.000,00 } & & \text { IFAD } \\ \text { Rp80.844.636.000,00 } & & \text { AIIB } \\ \text { Rp1.895.187.580.000,00 dan } & \text { IDA } & \text { Rp } \\ 169.000 .000 .000,00 . & & & \end{array}$

Dalam peraturan disebutkan bahwa hasil investasi pada LKI dicatat dalam Pendapatan Penerimaan Negara Bukan Pajak Lainnya (PNBP Lainnya). Pada tahun anggaran 2019, PNBP Lainnya dicatat sebesar Rp124.157.596.399.650,00 (sekitar 124,1 Triliun rupiah). (Gambar 2)

\begin{tabular}{|c|c|c|}
\hline Uraian & TA 2019 (Audited & TA 2018 Ludited \\
\hline Pendapatan dari Surplus Otcritas Jasa Kevangan & 795.220944 & 55.663 .300 .189 \\
\hline $\begin{array}{l}\text { Pendapatan dai Peniualan, Pengelolaan BMN, Iuran } \\
\text { Badan Usaha, dan Penerimaan Klain Asurarsi }\end{array}$ & 32.083 .100 .353 .355 & 46.946 .552 .039 .286 \\
\hline Pendapatan Adninistrasi dan Penegalan Hulum & 18.366 .375 .054 .747 & 17.768 .170 .773 .554 \\
\hline $\begin{array}{l}\text { Pendapatan Kesehatan Perlindungan Sosial dan } \\
\text { Keaganaan }\end{array}$ & 6.728 .386 .646 .421 & 7.421 .052335 .146 \\
\hline Pendapatan Pendidilan, Budaya, Riset dan Telnologi & 5.229 .029 .641 .870 & 4.763 .894 .209 .734 \\
\hline $\begin{array}{l}\text { Pendapatan Jasa Transportasi, Komunicasi đan } \\
\text { Infermatila }\end{array}$ & 25.903218 .006 .612 & 23.950 .487 .055 .396 \\
\hline Pendapatan Jasa Laimya & 429.902 .216 .890 & 910.056 .355 .732 \\
\hline $\begin{array}{l}\text { Pendapatan Bunga, Pengelolaan Relcening Perbarkan } \\
\text { dan Pengelolaan Keuangan }\end{array}$ & 19.333 .882 .339 .344 & 11.153 .269 .856 .791 \\
\hline Pendapatan Denda & 614.389 .891 .175 & 611.724 .687 .653 \\
\hline Pendapatan Lain-lain & 15.468 .517 .028 .292 & 14.701 .615 .716 .000 \\
\hline Jumlah PNBP Lainnya & 124.157 .596 .399 .650 & 128.282 .486 .329 .481 \\
\hline
\end{tabular}

Gambar 2. PNBP Lainnya TA 2019

(Sumber: LKPP TA 2019)

Mencermati gambar 2 di atas, tidak ditemukan penerimaan hasil investasi pada LKI. Demikian juga dengan pendapatan PNBP pada tahun tahun sebelumnya. Berdasarkan pengamatan terhadap LKPP tahun anggaran 2004 sampai dengan 2019, pemerintah tidak pernah mencatat adanya pendapatan yang berasal dari LKI. Pada Tabel 1 di bawah menginformasikan mengenai Pendapatan Pemerintah Pusat yang berasal dari PNBP (Penerimaan Negara Bukan Pajak) dan salah satu unsur PNBP yaitu Pendapatan dari LKI dari tahun 2004 s.d 2019. Perlu diinformasikan bahwa proses penyusunan LKPP yang sesuai dengan Standar Akuntansi Pemerintahan baru dimulai pada tahun anggaran 2004. Berdasarkan data tersebut, tujuan investasi pada LKI untuk memperoleh manfaat ekonomi belum terlihat hasilnya sampai dengan saat ini.

Copyright (C) 2020, FINANCIAL: Jurnal Akuntansi
Tabel 1. PNBP dan Pendapatan LKI

\begin{tabular}{|c|c|c|c|c|c|}
\hline \multicolumn{7}{|c|}{ PNBP DAN PENDAPATAN DARI LKI } \\
DALAM TRILIUN RUPIAH \\
\hline Tahun & PNBP & LKI & Tahun & PNBP & LKI \\
\hline 2004 & 122 & 0 & 2012 & 351 & 0 \\
\hline 2005 & 146 & 0 & 2013 & 354 & 0 \\
\hline 2006 & 226 & 0 & 2014 & 398 & 0 \\
\hline 2007 & 215 & 0 & 2015 & 255 & 0 \\
\hline 2008 & 320 & 0 & 2016 & 261 & 0 \\
\hline 2009 & 227 & 0 & 2017 & 311 & 0 \\
\hline 2010 & 268 & 0 & 2018 & 409 & 0 \\
\hline 2011 & 331 & 0 & 2019 & 408 & 0 \\
\hline
\end{tabular}

\section{Investasi Pada LKI Bertujuan Memperoleh Manfaat Sosial}

Tujuan pemerintah melaksanakan APBN berbeda dengan perusahaan swasta dalam pengelolaan dananya. Perusahaan swasta/badan usaha milik pemerintah secara umum mengutamakan keuntungan finansial sesuai dengan target yang dicanangkan. Berbeda dengan perusahaan swasta/ badan usaha pemerintah. 
Pemerintah dalam melaksanakan APBN mempunyai berbagai macam tujuan sesuai dengan yang tercantum dalam UndangUndang APBN. Selain motif ekonomi, pemerintah juga memiliki tujuan ideologis, politik, sosial, budaya dan pertahanan keamanan.

Begitu juga dengan tujuan pemerintah dalam berinvestasi. Selain motif ekonomi, di mana pemerintah menargetkan perolehan dividen, bunga dan lain-lain, pemerintah juga menginginkan adanya manfaat sosial dalam investasi yang ditanamkannya. Pemerintah tidak akan memperoleh manfaat ekonomi secara langsung ketika membangun jalan, jembatan, gedung pelayanan publik, dan lain-lain. Namun ada manfaat sosial yang akan diperoleh dari penanaman modal tersebut. Demikian juga ketika pemerintah menanamkan modalnya pada LKI. Selain manfaat ekonomi, sesuai dengan tujuannya juga diharapkan terdapat manfaat sosial yang bisa diperoleh.

Berdasarkan Nota Keuangan Pemerintah Pusat Tahun Anggaran 2020, tujuan dari investasi kepada LKI yaitu a) untuk memenuhi kewajiban negara sebagai anggota pada LKI tersebut. Pada setiap keanggotaan Indonesia pada LKI, pemerintah memiliki hak dan kewajiban yang sudah ditentukan. Berdasarkan PP Nomor 98 Tahun 2015, hak pemerintah Indonesia di LKI antara lain hak Tarik khusus, menerima bunga hasil penempatan, menerima fasilitas pinjaman. Sedangkan kewajibannya antara lain melakukan pembayaran kuota yang merupakan klaim atas partisipasi keanggotaan; b)untuk mempertahankan porsi kepemilikan/ shares; dan c) untuk mempertahankan hak suara/ voting rights pemerintah Indonesia.
Dengan mempertahankan porsi kepemilikan dan hak suara maka kepentingan Negara Indonesia dalam pengambilan keputusan di masing-masing LKI dapat lebih dijaga. Selain itu investasi kepada LKI juga dapat meningkatkan martabat Indonesia dalam pergaulan Internasional.

\section{SIMPULAN DAN SARAN}

Berdasarkan analisa di atas, dapat disimpulkan a) Tujuan investasi Pemerintah Indonesia pada LKI adalah untuk memperoleh manfaat ekonomi seperti bunga, dividen, dan royalti, atau manfaat sosial sehingga dapat meningkatkan kemampuan pemerintah dalam rangka pelayanan kepada masyarakat, b) Berdasarkan data yang terdapat dalam Laporan Keuangan Pemerintah Pusat Tahun Anggaran 2004 sampai dengan 2019 (enam belas periode), pemerintah tidak pernah mencatat adanya pendapatan yang berasal dari penanaman modal pada LKI, seperti pendapatan dividen, bunga atau pendapatan dalam bentuk lainnya, dan c) Berdasarkan Nota Keuangan Pemerintah, dengan adanya penanaman modal pada LKI tersebut, Negara Indonesia telah memperoleh manfaat sosial, antara lain eksistensi Negara Indonesia di forum pergaulan internasional, kemudahan memperoleh fasilitas pinjaman dan hak keanggotaan lainnya.

Terdapat keterbatasan dalam penulisan ini antara lain tidak diperoleh data tentang laporan keuangan LKI. Apabila laporan keuangan LKI tersebut bisa diperoleh, maka akan muncul informasi mengenai laporan laba rugi LKI dan pembagian keuntungan/kerugiannya. 
Berdasarkan kesimpulan di atas, terdapat saran yang bisa dilakukan oleh Pemerintah yaitu a) Pemerintah perlu mempertimbangkan kembali pencatatan pembayaran iuran kepada LKI sebagai investasi permanen pada LKI. Dalam kurun waktu 16 tahun terakhir, pemerintah tidak mencatat adanya hasil investasi tersebut, baik dalam bentuk dividen, bunga dan lainnya. Karena pembayaran iuran kepada LKI tersebut dilakukan hampir setiap tahun, kemungkinan bisa dipertimbangan bahwa pembayaran iuran tersebut dicatat sebagai beban (expense). Dalam Peraturan Menteri Keuangan Nomor 214/PMK.05/2013 tentang Bagan Akun Standar, disebutkan bahwa iuran pemerintah yang dibayarkan kepada lembaga internasional dianggarkan pada akun 58411 Beban Iuran ke Lembaga Internasional. Dengan pencatatan pembayaran kepada LKI sebagai beban, maka laporan keuangan pemerintah lebih "sehat" karena tidak terdapat investasi yang tidak menghasilkan pendapatan (imbalan), b) Pemerintah perlu memperluas pengertian manfaat sosial sebagai kemampuan pemerintah memberikan pelayanan kepada masyarakat. Kemungkinan bisa ditambahkan sebagai manfaat agar Negara Indonesia senantiasa aktif dalam kancah pergaulan internasional.

\section{DAFTAR PUSTAKA}

Danawati, S., Bendesa, I. K., \& Utama, M. S. (2016). Pengaruh Pengeluaran Pemerintah Dan Investasi Terhadap Kesempatan Kerja, Pertumbuhan Ekonomi Serta Ketimpangan Pendapatan Kabupaten/Kota Di Provinsi Bali. E-Jurnal Ekonomi Dan Bisnis Univeristas Udayana.

Dixit, A. K., \& Pindyck, R. S. (2012).
Investment under uncertainty. In Investment under Uncertainty. https://doi.org/10.2307/1909571

Gupta, M. R. (1984). Migration, unemployment and development. A dynamic two-sector analysis. Economics Letters. https://doi.org/10.1016/01651765(84)90160-5

Hamad, I. (2004). KONSTRUKSI REALITAS POLITIK DALAM MEDIA MASSA (Studi Pesan Politik Dalam Media Cetak Pada Masa Pemilu 1999). Makara Human Behavior Studies in Asia. https://doi.org/10.7454/mssh.v8i1.77

Hartono M, J. (2015). Teori portofolio dan analisis investasi (edisi Kesepuluh). In Yogyakarta: BPFE.

Kolitz, D. (2014). Financial accounting. In Financial Accounting. https://doi.org/10.4324/97802037846 55

Mankiw. (2013). Mankiw Principles of Economics. In Journal of Chemical Information and Modeling. https://doi.org/10.1017/CBO9781107 415324.004

Meltzer, J. P. (2009). Investment. In Bilateral and Regional Trade Agreements: Commentary and Analysis. https://doi.org/10.1017/CBO9780511 575983.010

Psacharopoulos, G., \& Patrinos, H. A. (2004). Returns to investment in education: A further update. Education Economics. https://doi.org/10.1080/09645290420 00239140

Sobur, A. (2006). Analisis Teks Media: Suatu Pengantar untuk Analisis Wacana. In Analisis Semiotik dan Analisis Framing. https://doi.org/10.1177/15248380073 02594

Peraturan Pemerintah Nomor 71 Tahun 2010 tentang Standar Akuntansi Pemerintahan. Presiden Republik 
Indonesia, 22 Oktober 2010

Laporan Keuangan Pemerintah Pusat

Tahun Anggaran 2019. Kementerian

Keuangan, Juni 2020

Peraturan Menteri Keuangan Nomor

50/PMK.010/2019 tentang

Penambahan Investasi Pemerintah

Republik Indonesia pada Lembaga

Keuangan Internasional Tahun

Anggaran 2019. Menteri Keuangan, 26 April 2019.

Peraturan Menteri Keuangan Nomor 169/PMK.05/2018 tentang Sistem Akuntansi dan Pelaporan Keuangan Investasi Pemerintah. Menteri Keuangan, 21 Desember 2018

Peraturan Menteri Keuangan Nomor 214/PMK.05/2013 tentang Bagan Akun Standar. Menteri Keuangan, 31 Desember 2013.

Pernyataan Standar Akuntansi Keuangan (PSAK) Nomor 15 tentang Akuntansi untuk Investasi dalam Perusahaan Asosiasi, Ikatan Akuntan Indonesia.

\section{PROFIL SINGKAT}

Penulis lahir di Kendal 23 Agustus 1973. Menempuh pendidikan Program Diploma 3 Akuntansi (lulus 1995) dan Program Diploma 4 Akuntansi (lulus 2001) di Sekolah Tinggi Akuntansi Negara (STAN). Pendidikan magister ditempuh di Magister Sains Ilmu Ekonomi Universitas Gadjah Mada Yogyakarta (lulus tahun 2009). Saat ini menjadi dosen di Politeknik Keuangan Negara STAN Jakarta. 